\title{
A STUDY ON THE STUDENTS' FACTOR DIFFICULTY IN WRITING NARRATIVE TEXT AT VIII GRADE OF MTs SABILAL MUHTADIN TEMBILAHAN
}

\author{
Nurul Asiah ${ }^{1}$, Edi Ardian $^{2}$, Samsul Amri $^{3}$ \\ English Study Program \\ Universitas Islam Indragiri - Tembilahan ${ }^{1,2,3}$
}

\begin{abstract}
Writing is one of the language skills, which is taught to secondary school students. In reality, it is still found that students have difficulties in writing. It is needed to investigate why it happened. Thus, the purpose of this research is to determine the students' factor difficulties in writing a narrative text. Moreover, it was designed as descriptive research which took sixty students of the eighth grade of MTs Sabilal Muhtadin Tembilahan as the samples. In collecting the data, the researchers used questionnaires and interviews. Then the data were analyzed by using descriptive statistical analysis and qualitative analysis. The research findings show that there are two main factors; students' factors and teachers' factors. After analyzing the data, the results revealed that the students' factor gained a percentage of $62.43 \%$ which was placed at a strong level. Also, the teachers' factor obtained a percentage of $72.95 \%$ which was classified as a strong level. The highest students' factor indicator was the statement "English is very different from Bahasa Indonesia." It was proven by the score $75.3 \%$ which was categorized as a strong level. Then the teachers' factor found that the highest indicator was the statement "Using up to date method and technique." It was classified as a strong level. In conclusion, the factors of students' difficulties in writing narrative text cause both students' and teachers' factors.
\end{abstract}

Keywords: Writing, Narrative Text, Factor Difficulty

\section{INTRODUCTION}

Writing is one of four language skills which is faced by the students when they learn English. Writing practice can help the students improve their vocabulary and of course, increase their ability in grammar. In other words, writing is useful for many purposes. Writing is an important tool for students not only in learning but also in communication. Nevertheless, the most important reason for students to acquire good writing skills is to use writing in their creative ways to interact effectively with people and the world around us.

The principle, to write means to try to produce or reproduce written messages. According to Eric Gould (1989: 18), writing is a creative act, the act of writing is creative 
because it requires interpreting or making sense of something: an experience, a text, and an even. In writing activity, the students are expected to be able to enrich their views about the topic they want to write as well as to improve their technique in the writing task. However, a great number of people agree to say that writing is a difficult task to do because of its complexity. Such an assumption appears to be true because it requires many efforts, much time, and great attention from the writer toward the topic as well as the writing process itself.

There are many kinds of material of writing that taught in the second grade of junior high school, for example, is genre, narrative, descriptive, recount, procedure, and so on. One of them is narrative. Based on the content of 2013 curriculum (K-13) students should be able to write Narrative they are at Grade VIII. Therefore, the narrative should be learned by the students.

A narrative text is a kind of text that focuses on the specific participant. Its social function is to tell stories of past events and entertain the readers. In reading narrative text, students should be aware of the structure of the narrative text (orientation, complication, and resolution). In orientation, the researcher refers to the participants and informs the time and the place. Then, it is continued the rising crises which the participants have to do with the complication. In the end, it will found the way of the participant to solve the crises, happy or sad resolution.

Some factors contribute to poor writing skills for Junior High School students. It is caused writing skill is the most complex and difficult skill to master. Richards and Renandya (2003: 303) argued that there is no doubt that writing is the most difficult skill for second language learners to master. Like the sample, the problems that are found that some of the students at VIII Grade students of MTs Sabilal Muhtadin Islamic Boarding School always say that they could not write well of narrative text in English. They get difficulties in vocabulary and the ideas of writing. In this case, some of the students often cheat one another in a writing session and cannot able to develop their writing. Also, the classroom situation shows that the students did not directly do the task given. Some of them are indicated not too interested in the writing lesson. 
the students got a lack of vocabulary, students got difficulties to write the right description and choose a word of an object when they are doing a task. Consequently, these factors affect the quality of student writing. For this reason, to know the actual data about the factors students' difficulty in writing narrative text.

\section{LITERATURE REVIEW}

\section{Writing Skill}

Writing may be just using graphic symbols or reproducing in written form something which has been heard or read. Hyland (2003: 3) defined that writing is not just arranging words into a sentence, linking the sentences into a paragraph, and ordering the paragraphs into a text. It also requires grammatical and lexical knowledge, understanding in applying the grammatical knowledge into different contexts and purposes and knowledge of topics that are going to be written he also states that writing requires thinking and learning to engage the writers' ideas to the readers.

According to Badger (2000:154) in Harnita (2013:6) "writing processes, approaches are seen as predominantly to do with linguistic skills, such as planning and drafting, and there is much less emphasis on linguistic knowledge, such as knowledge about grammar and text structure".

Writing is one of the language skills, which is used as one medium to communicate with others. In other words, one way to express the language is through written form. Since writing is used as one form of communication, mastering the skill of writing is needed because by writing, people especially the students will enable them to express their ideas, feelings, and experiences in a certain pale time and situation in written form. Writing can be defined as a way of expressing ideas through written forms. Hughey, et.al (1983: 33), stated that writing is an essential form of communication because, through writing, we can express our feelings, hopes, dreams, and joy as well as our fears, fits of anger, and frustrations. He also adds that that writing is a transcription of the process of composing ideas; it is not the product of thought but it is actualization and dramatization. Writing is a 
complex process because writing cannot be just mentioned as the written word but it is more about the process, procedure, and steps in resulting that written work.

From the explanation above, it can be concluded that writing is one method of communication to other people to express ideas. It can be using symbols, graphics, and written form.

\section{The Factors of Students' Difficulty in Writing}

Many learners assume that the key to a good English written production is mastering the rules of grammar, but what about the other aspects of writing? In this respect, the learners often rush towards more grammatical practice and tend to forget about practicing the specific rules of writing such as drafting, revising, editing, etc. These rules are summarized by Harmer (2007: 4), he states that writing is a process, that is, the stages the writer goes through to produce something in its final form. This process may, of course, be affected by the content of the writing, the type of writing, and the medium it is written, this process has four main elements: planning, drafting, editing, and final draft.

According to Richards and Schmidt (2002: 529), writing is viewed as a result of complex processes of planning, drafting, reviewing, and revising. It means, in writing, we should have planned before we start to write, such as about what is the topic we will talk about. After that, we should make a draft about the topic one by one that will we combine or arrange or explain later. Then, after we have some drafting about the topic, we will review again our writing, is that good or not, is that suitable for the topic or not. Then, finally, forget the better writing result; we should check again our writing by revising the step.

There is a common agreement that writing is the most complex and difficult skill for it requires a lot of training. Like all learning problems, difficulties in producing a good piece of writing can be devastating to the learners' education, self-esteem, self-confidence, and motivation to write. Many researchers (Yakoob, 2010: 7) agreed that writing is the most complex and difficult skill. This difficulty lies not only in generating and organizing ideas but also in translating these ideas into readable text. And since the teaching/learning process cannot take place only with the presence of the teacher and the learner, this 
research will be entirely devoted to speaking about the influence of teachers' and students' capabilities that will affect the students writing skills.

We are perfectly aware that there is an almost endless number of factors that affect students' achievements in writing. These factors could be related to the program, the methods, the techniques, the teacher, the learner, and others such as motivation, anxiety, etc. But, we have deliberately limited our study to what we think are the main factors that are related to both teachers and learners. For that reason, according to Nacira (2010: 7) stated the factors that hamper students to write can be from two sources, teacher's side and students' side. They are:

\section{From the teacher}

a. The use of methods and techniques that are relevant to teach writing.

Teachers' main task is choosing the best classroom technique. This latter is the day-to-day business of every writing teacher. Selecting these techniques depend on their suitability with class, students' levels, and the approach underlying the curriculum and teaching. (Nacira, 2010: 63).

b. Teacher's motivation for students to write.

There is no teacher teaches in the same way under the same conditions. Accordingly, the teachers have some crucial tasks to perform to help the students become better-good writers. Harmer (2007: 41) stated that "the main task of the teacher is to motivate and provoke the students." In other words, student writers often find themselves "lost for words" especially when dealing with creative writing. Here the teacher's role is to provoke the students to have ideas, enthusing them with the value of the task, etc. Sometimes, teachers can help the students by worth words they need to start writing.

In this respect, Harmer (2007: 42) added another issue which is closely allied to the teacher's role as motivator and provoker is that of support. This means that students still need a lot of help and reassurance once they get going. Teachers must be extremely supportive when students engage in writing, by helping them overcome difficulties. 
c. Teacher's corrective feedback and reinforcement.

Feedback is very important in teaching a foreign language; in teaching, feedback refers to comments or other information that learners receive concerning their success on learning tasks or tests, either from the teacher or other persons.

By "correcting", we mean correcting mistakes of a student's written performance on issues such as syntax, grammar, collocation, etc. When teachers' intervention is designed to help students edit and move to another new draft, responding is more appropriate than correcting. This means that our task, as teachers, is not to say what wrong or right, but to ask questions, make suggestions, and indicate where the student could improve his writing either in the content or in the manner of his expression. This type of feedback will improve the students' level and they can take advantage of such help. (Nacira, 2010: 67)

d. Teacher's responses to students' written production

When responding to students' work, it means that the teachers react, to the content and the way the piece of writing is constructed, supportively by giving suggestions, asking questions, etc. and not grading the work or judging it as a finished product. Moreover, the teacher tells the students how well they are going so far; by making comments concerning the correct use of language and suggesting other ways to improve writing. In this respect, Raimes (1994: 139) suggested that "responding to student's writing is very much a part of the process of teaching writing."

Responding to students' work can be done by writing comments, after handing the draft to the teacher. In such circumstances, the teacher should write comments that encourage, foster and enthuse the students to carry on their writing.

\section{From the students}

a. Lack of motivation to write

Motivation is strongly related to achievement, and learners' motivation makes the mission easier and more pleasant for both teachers and learners. In this case, motivation makes writing pleasant and enjoyable. There are two questions that 
language skill teachers frequently pose to writing. First, why are students so often not motivated to write? Second, how can their motivation to write be increased?

Learners do write because they see their friends write or maybe they are under the influence of their teachers. But when they write, they are prompted by uncertainty; they feel doubtful about what they write. Moreover, some students avoid showing their writing; they intentionally hide their weaknesses and often do not finish on purpose because they are utterly pessimistic and feel a beforehand failure. The idea of failure should not be let to creep in the learners' consciousness, yet we cannot get rid of it. (Nacira, 2010: 76)

That is, the main role of a teacher is to enhance, to encourage the students to write by making writing stimulating and enjoyable as it is reported by Dornyei (2005: 80) who claims that "It is one thing to initially whet the student's appetite with appropriate motivational techniques". In other words, the teacher should be selective in choosing or exposing the students to attractive topics and determines the objective of writing such topics. Moreover, students feel relaxed when expressing their thought, ideas, etc., in writing; however, they find great difficulties in writing in English.

b. Lack of reading

Reading and writing are two skills that are separated, for reading is a passive activity while writing is a productive one, they are nonetheless complementary and can be closely developed.

Furthermore, reading in the classroom is understood as the appropriate input for the acquisition of writing skills for it is generally assumed that reading passages will somehow function as primary models for which writing can be learned or at least inferred. (Nacira, 2010: 80).

This means that, when the students read, they engage actively with the new language and culture, in our case, it is English which they have little occasion to speak or hear spoken face to face. She goes on to claim that "the more our students read, the more they become familiar with the vocabulary, idiom, sentence patterns, organizational flow, and cultural assumptions of native speakers of the language" In other words, reading is a pre-condition for writing because it plays an important role in 
its development. One cannot improve writing if he does not read frequently (Raimes, 1994: 60-66).

c. The influence of the first language (L 1) on writing in English.

Writing conventions differ from one language to another. In any way, not any person is a naturally gifted writer. Writing is a skill that can be learned, practiced, and mastered. Writing remains the most difficult skill to be mastered even for native speakers.

It can be caused that writing is a very complex cognitive activity in which writers must show control over content, format, sentence, structure, vocabulary, punctuation, spelling, and letter formation, i.e., control at the sentence level. Besides, writers must be able to structure and integrate information cohesively and coherently within paragraphs and texts. (Nacira, 2010: 84)

\section{Narrative Text}

According to Montgomery (2007: 251), narratives are stories involving a sequence of related events. There are various kinds of relationships between events in a narrative. The most obvious kind is where one event causes another. Such causal connections link one event with another and function partly to give unity to the narrative and partly to enable the narrative to draw moral conclusions about the consequences of actions. He adds that the content of a narrative is a collection of represented events, along with the participants in those events, and the circumstances of those events.

According to Wardiman (2008:93), "A narrative text is an imaginative story to entertain people". Furthermore, Susilohadi (2008: 9) explains that narrative texts start with the orientation, which shows the scene and introduces the participants. Then, the complication tells the readers about the crisis that arises. Finally, the resolution tells the readers that the crisis is resolved for better or worse.

According to Hartono (2003: 6), "the purpose of Narrative text entertains the reader with the story. The narrative text has language features, according to Hartono (2003: 7) they are: using the simple past tense, past perfect, past continuous, past perfect continuous, and past future continuous. 
Many narratives contain morals and themes. For example, fables are short stories followed by an important moral point. According to Pearson and Fielding (1991: 89), students benefit from reading narrative texts. Therefore, reading instructors can use narratives to teach moral lessons. For that reason, according to Yimwilai (2009: 10), the narrative also has some genres, include:

1. Fantasy,

2. Fairy tales, folk tales, and tall tales,

3. Fables,

4. Historical fiction,

\section{RESEARCH METHOD}

This is descriptive research. Gay and Airasian (2009:10) said that descriptive research involves collecting data to answer questions concerning the current status of the subject of the study. Furthermore, the samples of the study were sixty students of the eighth grade of MTs Sabilal Muhtadin Tembilahan. In collecting the data, the researchers used two instruments; questionnaire and interview. The questionnaire was designed in the form of a Likert Scale by choosing Strongly Agree (SA), Agree (A), Undecided (U), Disagree (D), or Strongly Disagree (DS). The questionnaire consisted of 35 items of statements.

Table 1 Indicators of Questionnaire

\begin{tabular}{|c|l|l|}
\hline No & Students' Questionnaire Indicators & \multicolumn{1}{|c|}{ Teachers' Questionnaire indicators } \\
\hline 1 & Lack of motivation to write & $\begin{array}{l}\text { The use of methods and techniques to } \\
\text { teach writing. }\end{array}$ \\
\hline 2 & Lack of reading & $\begin{array}{l}\text { Teachers' motivation for assisting } \\
\text { students to write }\end{array}$ \\
\hline 3 & $\begin{array}{l}\text { The influence of the first language } \\
\text { (L1) on English writing }\end{array}$ & $\begin{array}{l}\text { Teachers' corrective feedback and } \\
\text { reinforcement }\end{array}$ \\
\hline 4 & - & $\begin{array}{l}\text { Teachers' responses to students' written } \\
\text { production }\end{array}$ \\
\hline
\end{tabular}

Then the interview was distributed to the students and teachers. It purposed to gain deep real factors of students' difficulty in writing narrative text. It was conducted to some students as a representative who had low, intermediate, and high writing skills. 


\section{FINDINGS AND DISCUSSION}

\section{Analysis of Students' Questionnaire}

The purpose of this research was to describe factually the students' factor difficulty in writing narrative text. There were three indicators of the students' writing difficulty that from the students' side; 1) Lack of motivation to write, 2) Lack of reading, and 3) The influence of the first language on writing in English. It consisted of fifteen items. The results of each indicator were as below:

Table 2 Students' Questionnaire Results

\begin{tabular}{|c|l|c|c|}
\hline No & \multicolumn{1}{|c|}{ Indicators } & Percentage & Classification \\
\hline 1 & Lack of motivation & $65.7 \%$ & Strong \\
\hline 2 & Lack of reading & $53.7 \%$ & Enough \\
\hline 3 & $\begin{array}{l}\text { The influence of the first } \\
\text { language on English writing. }\end{array}$ & $67.9 \%$ & Strong \\
\hline \multicolumn{2}{|c|}{ Total } & $\mathbf{1 8 7 . 3}$ & \\
\hline \multicolumn{2}{|c|}{ Mean Score } & $\mathbf{6 2 . 4 3}$ & Strong \\
\hline
\end{tabular}

Based on the questionnaire results, it was found that the average of lack of motivation to write indicator was $65.7 \%$, it was categorized as a strong factor. Then the average of Lack of reading was $53.5 \%$, which was classified as enough factor. The last the average of the influence of the first language on English writing indicator was 67.9\%, it was categorized as a strong factor.

The results show that the students' factor difficulties in writing narrative text were mostly influenced by the first language (Bahasa Indonesia) in their writing. Based on the items of this indicator, they felt that it is easier to write in Bahasa Indonesia than English $(66.0 \%)$, it is difficult to understand the meaning of English vocabulary (61.0\%), they often mix the use of Bahasa Indonesia with English (67.7\%), English is very different from Bahasa Indonesia (75.3\%), and it is hard to put ideas in English (69.7\%). Thus it can be implied that the first language has a significant impact on their English writing. In other words, most students got difficulty with this factor because the English Language is very different from Indonesian, such as, in choose of word or vocabulary, arranges of each word. It was also supported by the result of the interview, students express that writing English is difficult especially in choose vocabulary, arrange each word, besides that they were rare to 
use English in daily activities; they only use Indonesian, because Indonesian is their language/mother language.

\section{Analysis of Teachers' Questionnaire}

There were four indicators of the students' writing difficulty that come from the teachers'side; 1) The use of method and technique that are relevant to teach writing, 2) Teachers' motivation for students to write, 3) Teachers' corrective feedback and reinforcement, and 4) Teachers' responses to students' written production. It consisted of twenty items.

Table 3 Teachers' Questionnaire Results

\begin{tabular}{|c|l|c|c|}
\hline No & \multicolumn{1}{|c|}{ Indicators } & Percentage & Classification \\
\hline 1 & $\begin{array}{l}\text { The use of methods and } \\
\text { techniques that are relevant to } \\
\text { teach writing. }\end{array}$ & $80.1 \%$ & Strongest \\
\hline 2 & $\begin{array}{l}\text { Teachers' motivation for students } \\
\text { to write. }\end{array}$ & $71.9 \%$ & Strong \\
\hline 3 & $\begin{array}{l}\text { Teachers' corrective feedback } \\
\text { and reinforcement. }\end{array}$ & $69.1 \%$ & Strong \\
\hline 4 & $\begin{array}{l}\text { Teachers' responses to students' } \\
\text { written production. }\end{array}$ & $70.7 \%$ & Strong \\
\hline \multicolumn{2}{|c|}{ Total } & $\mathbf{2 9 1 . 8}$ & Strong \\
\hline
\end{tabular}

Based on the questionnaire results, it was determined that the average of The use of methods and techniques that are relevant to teach writing indicators was $80.1 \%$, it was categorized Strongest factor. Then the average of Teachers' motivation for students to write indicators was $71.9 \%$, which was classified as Strong factor. Next, the average of Teachers' corrective feedback and reinforcement indicator resulted in $69.1 \%$, it was placed as enough factor. Lastly, the average of Teachers' responses to students' written production indicators was $70.7 \%$, it was categorized as a strong factor.

The findings revealed that the students' factor difficulties in writing narrative text viewed from the teachers' factor were related to the use of technique and method used by the teachers in teaching writing. It was proven that this indicator was placed into the strongest factor. It included some situations; the method and teaching technique that are 
relevant to writing learning $(76.0 \%)$, the teachers use up to date method and technique $(82.3 \%)$, the teachers use method and technique that are liked by the students $(81.3 \%)$, the teachers implement method and technique that are suitable with the material/theory $(81.3 \%)$, and the teachers' method and technique in teaching writing are effective $(81.3 \%)$. It obviously determines that the teachers' ability in using and selecting appropriate methods and techniques in teaching writing influences the students' writing difficulties in English writing. In other words, the teacher was rare to use innovative or variation in using up to date methods and techniques or use the effect of new methods and techniques in teaching to make students interested in writing narrative. It was also supported by the results of an interview that some students display that just sometimes understand what teachers taught about. Although, some of them also stated that the teacher was patient enough in teaching writing.

\section{CONCLUSION}

This current study was proposed to investigate the students' factor difficulties in writing narrative text in the eighth grade of MTs Sabilal Muhtadin Tembilahan. Based on related theories and previous studies, there two factors that influence the students' difficulties in writing narrative texts; students' factor and teachers' factor. After analyzing the data, the results revealed that the students' factor gained a percentage of $62.43 \%$ which was placed at a strong level. Also, the teachers' factor obtained a percentage of $72.95 \%$ which was classified as a strong level. Moreover, most students' factor indicator that influences the students' writing difficulties was the perception of the students that English is very different from Bahasa Indonesia. Then the most teachers' factor indicator that causes their writing difficulties was relevant to the use of teaching methods and techniques used by the teachers in teaching the writing of narrative texts. It could be determined that the most factor influence on their writing skill was from the teachers' factor. Thus it is suggested that the teachers should use a compatible teaching writing method. 


\section{REFERENCES}

Arikunto, Suharsimi. 2010. Dasar-Dasar Evaluasi Pendidikan. Jakarta: BumiAksara.

\section{Cipta.} . 2010. Prosedur Penelitian: Suatu Pendekatan Praktik.Jakarta: Rineka

Creswell, John W. 2008. Educational Research; Planning, Conducting, and Evaluating Quantitative and Qualitative Research. New Jersey: Pearson Education, Inc.

Domyei, Z. 2005.The psychology of language learners: Mahwah. New Jerzy

Frankel, R. Jack \& Wallen, E, Norman. 2006. How to Design and EvaluateResearch in Education. New York: McGraw-Hill Companion.

Gay, L.R. \&Airasian, peter. 2009. Educational Research: Competencies for Analysis and Application. (6th ed.) . New Jersey: Merril Publishing Company.

Harmer, J. 2007. How to teach for exams. Pearson Education Limited. Harmer, J. 2007. How to teach writing. Pearson Education Limited.

Hartono, Rudi. 2003. Genre of Text. Semarang: UNNES.

Heaton, J.B. 1990. Writing English Language Tests. London: Longman Group.

Hughey, Jane B., et al. 1983. Teaching ESL Composition: Principles and Techniques. Laurence Erlbaum Associates.

Hyland, Ken. 2003. Second Language Writing. Cambridge: Cambridge UniversityPress. Massachusetts: Newbury House.

Montgomery, Martin. (2007). Ways of Reading Advanced Reading Skills for students of English Literature 3 Ed. New York: Routledge.

Naciram Ghobbane. 2010. Identification and Analysis of Some Factors Behind Students' Poor Writing Productions. Retrieved from https:/www.univ• setif.dz/Tdoctorat/images/stories/pdf_theses/facultes1Iarabe/naciraghothbene.pdf Accessed on 23rd, October 2016

Pearson, David; \&Fielding, Linda. 1991. Comprehension Instruction. Handbook of Reading Research. New York: Longman.

Raimes, A. (1994).Techniques in teaching writing. (3rd ed.). Oxford: O.U.P.

Soewadji, Jusuf. 2012. Pengantar Metodologi Penelitian. Jakarta: Mitra WacanaMedia. 
Susilohadi, G, et al. 2008. Contextual Teaching and Learning : Bahasa Inggris Sekolah Menengah Pertama Kelas IX Jakarta: Pusat Perbukuan Departemen Pendidikan Nasional.

Wardiman, et al. 2008. English in Focus for Grade VIII Junior High School.Jakarta: Pusat Perbukuan Departemen Pendidikan Nasional.

Yimwilai, Supapom. (2009). Using Narrative Texts to Teach Reading. Retrieved from http://ejoumals.swu.ac.th/index.php/hm/article/download/412/405. Accessed on 23rct, October 2016 